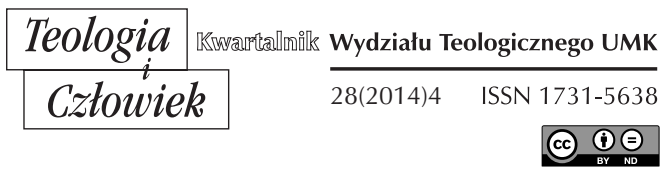

KS. DARIUSZ KWIATKOWSKI*

POZNAŃ

\title{
OBRZĘDY CHRZCIELNE DZIECI W OKRESIE OD VI DO IX WIEKU
}

DOI: http://dx.doi.org/10.12775/TiCz.2014.062

Praktyka chrztu dzieci zmieniała się na przestrzeni wieków. W starożytności znajdujemy zarówno zwolenników, jak i przeciwników udzielania tego sakramentu niemowlętom. Trzeba jednak powiedzieć, że w oficjalnym nurcie kościelnego nauczania nigdy nie istniał zakaz chrzczenia dzieci, a wprost przeciwnie - największe autorytety starożytnego Kościoła i liczne synody zachęcały do tej praktyki.

Począwszy od VI wieku, sytuacja Kościoła w ówczesnym świecie bardzo się zmieniła. Chrześcijaństwo stało się religią dominującą i obowiązującą niemal $\mathrm{w}$ całej Europie. W tym kontekście instytucja katechumenatu, zajmująca się do tej pory przygotowaniem dorosłych do przyjęcia chrztu, przestała być potrzebna. Praktycznie od VI wieku zaczęto masowo chrzcić małe dzieci. Ta zmiana musiała doprowadzić do reorganizacji obrzędów przygotowania i udzielania sakramentu chrztu.

We wszystkich księgach liturgicznych znajdujemy starożytną formułę lex orandi $=$ lex credendi. $\mathrm{W}$ księgach liturgicznych zawierających

* Ks. prof. UAM dr hab. Dariusz Kwiatkowski jest kapłanem diecezji kaliskiej. Obecnie pracuje w WSD w Kaliszu i jest adiunktem Wydziału Teologicznego UAM w Poznaniu. Jest członkiem Rady Naukowej Czasopisma „Teologia i Człowiek”. 
teksty modlitw i opisy celebracji liturgicznych Kościół zawsze wyrażał swoją wiarę. Tak też jest $\mathrm{w}$ księgach, w których zamieszczono obrzędy chrztu. Do najstarszych ksiąg liturgicznych w sensie ścisłym, które podają opis liturgii chrzcielnej, należą Sakramentarz gelazjański oraz Ordo Romanus $\mathrm{XI}^{1}$. Celem artykułu jest przedstawienie obrzędów chrzcielnych umieszczonych $w$ obu księgach, zawierających opis liturgii chrzcielnej z okresu między VI a IX wiekiem. Najpierw jednak w skrócie omówione zostanie nauczanie Kościoła starożytnego dotyczącego chrztu dzieci.

\section{PRAKTYKA CHRZTU DZIECI W NAUCZANIU STAROŻYTNEGO KOŚClOŁA}

W Dziejach Apostolskich można znaleźć wiele historycznych informacji o sposobie udzielania sakramentu chrztu przez apostołów i ich uczniów. Co do możliwości udzielania chrztu dzieciom na szczególną uwagę zasługują następujące teksty: Dz 10 - historia nawrócenia i chrzest całej rodziny Korneliusza; Dz 16,30-33 - chrzest strażnika więziennego w Filippi oraz jego rodziny; Dz 18,8 - uwierzenie w Chrystusa i przyjęciu chrztu przez całą rodzinę przełożonego synagogi Kryspusa. W czasach apostolskich chrzczono zasadniczo dorosłych, choć teksty mówiące o nawracaniu się i chrzcie całych rodzin dowodzą, że sakramentu udzielano także dzieciom² ${ }^{2}$ O chrzcie dzieci świadczą również inskrypcje znajdujące się na grobach. Podają one wiek ochrzczonego dziecka. Wynika z nich, że nie chodzi o jakieś nadzwyczajne przypadki, ale o normalny chrzest udzielany podczas Wigilii Paschalnej ${ }^{3}$.

Instrukcja o chrzcie dzieci Pastoralis actio, wydana w roku 1980 przez Kongregację Nauki Wiary, mówi o niepamiętnej praktyce udzielania chrztu dzieciom. Dokument odwołuje się do starożytnych świadectw Ireneusza, Orygenesa, św. Augustyna. Zwraca uwagę, że choć pierwsze wyraźne świadectwa pochodzą z II wieku, to jednak żadne z nich nie przedstawia chrztu jako czegoś nowego. Według św. Ireneusza jest czymś

${ }^{1}$ W kolekcji PL obrzędy katechumenalne i chrzcielne oznaczone są numerem VII. Ponieważ korzystamy ze zbioru M. Andrieu, będziemy używać jego numeracji, czyli XI.

2 Por. B. Mokrzycki, Droga chrześcijańskiego wtajemniczenia, Warszawa 1983, s. 52.

${ }^{3}$ Por. B. Nadolski, Liturgika, t. 3: Sakramenty, sakramentalia, błogosławieństwa, Poznań 1992, s. 31. 
oczywistym i zgodnym z tradycją wyliczanie wśród ochrzczonych niemowląt i dzieci wraz z osobami dorosłymi ${ }^{4}$.

Bardzo wyraźne świadectwo o chrzcie dzieci znajdujemy w Tradycji apostolskiej, pochodzącej z początków III wieku. W części opisującej liturgię chrzcielną czytamy: "Gdy się rozbiorą, należy rozpocząć od chrztu dzieci. Jeśli potrafią one odpowiadać same, niech odpowiadaja, jeśli nie, mają za nie odpowiadać rodzice lub ktoś z rodziny. Następnie przystąpią do chrztu dorośli mężczyźni..."5. Należy zwrócić uwagę, że autor dzieła nie widzi nic nadzwyczajnego w praktyce chrzczenia dzieci. Nie ma tutaj żadnego wyjaśnienia czy komentarza, co może świadczyć, że była to powszechnie przyjęta praktyka.

O chrzcie dzieci bardzo wyraźnie mówił też św. Cyprian na synodzie w Kartaginie. W roku 253 zebrało się tam 66 biskupów pod przewodnictwem św. Cypriana, aby odpowiedzieć na list biskupa Fido, który miał wątpliwości dotyczące wczesnego chrztu niemowląt. Biskup ten uważał, że należy chrzcić niemowlęta nie wcześniej jak w ósmy dzień po narodzinach. W odpowiedzi zgromadzenie biskupi napisali: „Na twój pogląd nikt się nie zgodził, lecz raczej wszyscy sądziliśmy, że żadnemu urodzonemu dziecku nie można odmawiać miłosierdzia Boga i łaski. Pan przecież mówi w swej Ewangelii: 'Syn Człowieczy nie przyszedł zatracać dusze, lecz zbawiać' (Łk 9,56), i o ile to jest w naszej mocy, powinniśmy się starać, aby nie zginęła żadna dusza ludzka"6. W dalszej części listu znajdujemy także teologiczne uzasadnienie chrztu dzieci. Cyprian zwraca uwagę, że wszyscy ludzie, zarówno dzieci, jak i dorośli, mają równy udział w darach Bożych. Wynika to z faktu, że wszyscy ludzie zostali stworzeni przez Boga. Poza tym dla Boga i Jego łaski wiek człowieka nie stanowi żadnej różnicy. Bóg obdarza swoją łaską w jednakowy sposób wszystkich ludzi. Stąd też nikomu nie należy przeszkadzać w otrzymywaniu Bożej łaski ${ }^{7}$.

${ }^{4}$ Św. Ireneusz, Adversus haereses, II, 22,4: PG 7, 784; cyt. za: Kongregacja Nauki Wiary, Instrukcja o chrzcie dzieci Pastoralis actio, nr 4, w: Chrzest w życiu i misji Kościoła. Materiaty z trzeciego Sympozjum Liturgicznego Diecezji Siedleckiej, Siedlce, 19 listopada 2005 roku, red. I. Chłopowska, W. Kazimieruk, Warszawa-Siedlce 2006, s. 180-181.

${ }^{5}$ Tradycja apostolska, nr 44. Tekst polski za: M. Michalski, Antologia literatury patrystycznej, t. 1, Warszawa 1975, s. 310.

${ }^{6}$ Cyprian z Kartaginy, List 64 o chrzcie dzieci, II, w: opr. A. Baron, H. Pietras, Dokumenty synodów od 50 do 381 roku, t. 1, Kraków 2006, s. 13*.

7 Tamże, nry III-V, s. $13^{*}-14^{*}$. 
Paradoksalnie, praktyka udzielania chrztu dzieciom przeszła pewien kryzys po tym, jak chrześcijaństwo stało się jedyną obowiązującą religią w Cesarstwie Rzymskim, a więc pod koniec IV wieku. W tamtym okresie dorośli odkładali swój własny chrzest, obawiając się przyszłych grzechów i publicznej pokuty. Z tych też powodów rodzice odkładali chrzest swoich dzieci. Należy jednak zwrócić uwagę, że ojcowie i doktorzy Kościoła tamtych czasów - sami ze względu na podane powody ochrzczeni w wieku dojrzałym - piętnowali praktykę odkładania chrztu dzieci. Można tu wymienić choćby św. Bazylego, św. Grzegorza z Nyssy, św. Ambrożego, św. Jana Damasceńskiego, św. Hieronima i św. Augustyna8.

Bardzo znaczącą wypowiedź dotyczącą chrztu dzieci znajdujemy w dokumentach synodu w Kartaginie z 418 roku. W kanonie drugim synodu czytamy: „,...ktokolwiek przeczy, że należy chrzcić małe dzieci zaraz po wyjściu z ciał matek, albo mówi, że się je chrzci wprawdzie dla odpuszczenia grzechów, lecz nie ściągają one na siebie z Adama nic z grzechu pierworodnego, który miałby być zgładzony przez kąpiel odrodzenia, z czego wynika, że u tych dzieci forma chrztu 'dla odpuszczenia grzechów' nie jest prawdziwa, lecz fałszywa w rozumieniu, ten niech będzie obłożony anatemą" . Synod wyjaśnia także, że to zgodnie z zasadami wiary chrzci się małe dzieci dla odpuszczenia grzechów. Kanon odwołuje się w tym miejscu do nauczania św. Pawła z Listu do Rzymian, w którym apostoł zdecydowanie naucza, że „Przez jednego człowieka grzech wszedł do świata, a przez grzech śmierć, i w ten sposób śmierć przeszła na wszystkich ludzi; w nim wszyscy zgrzeszyli $(5,12)$. Tej zasadzie podlegają także niemowlęta i dlatego przez chrzest zostają oczyszczone i rodzą się do nowego życia ${ }^{10}$.

\section{SAKRAMENTARZ GELAZJAŃSKI I ORDO ROMANUS XI}

W tej części artykułu przedstawimy krótką charakterystykę obu ksiąg liturgicznych, uwzględniając tylko części dotyczące inicjacji chrze-

${ }^{8}$ Zob. Kongregacja Nauki Wiary, Instrukcja o chrzcie dzieci Pastoralis actio, nr 5, s. 181-182.

${ }^{9}$ XV (i XVI) Synod w Kartaginie, Grzech pierworodny, kan 2, w: Breviarium Fidei. Wybór doktrynalnych wypowiedzi Kościota, red. I. Bokwa, Poznań 2007, nr 49, s. 50 (dalej: BF).

${ }^{10}$ Por. tamże. 
ścijańskiej. W Sakramentarzu gelazjańskim można wyodrębnić trzy sekcje zawierające formularze liturgiczne związane z inicjacją chrześcijańską:

- od XXVI do XXXVI';

- od XLII do XLIV'12;

- od LXVI do LXXVI ${ }^{13}$.

Trzeba podkreślić, że poszczególne sekcje nie pochodzą z tego samego okresu. Przyjmuje się ogólnie, że teksty liturgiczne najstarszego zachowanego manuskryptu powstały od VI do VII wieku. Trwają dyskusję między znawcami epoki i ksiąg liturgicznych co do zależności Sakramentarza gelazjańskiego i Ordo Romanus XI. Według Michel Andrieu niektóre części Gelazjanum zostały wzięte z Ordo Romanus XI. Natomiast Antoine Chavasse nie zgadza się z tą opinią i uzasadnia, że to Ordo Romanus XI bierze teksty z rzymskiego sakramentarza. Rytuał chrzcielny znajdujący się w Sakramentarzu gelazjańskim powstawał w trzech etapach. Do najstarszych sekcji należy zaliczyć obrzędy znajdujące się w rozdziałach: od XXX do XXXII, od XXXV do XXXVI i od XLII do XLIV. Druga epoka powstania obrzędów chrzcielnych to rozdziały od LXVI do LXVII. Najmłodsze części znajdują się w rozdziałach: XXIX A-B i od XXXIV do XXXV ${ }^{14}$.

Wczytując się $\mathrm{w}$ teksty modlitw oraz rubryki dotyczące inicjacji obecne w Sakramentarzu gelazjańskim, łatwo zauważyć, że dotyczą one małych dzieci. Można wymienić choćby następujące przykłady: sekcja XXVI: qui ipsos infantes suscepturi sunt ${ }^{15}$, sekcja XXVIII: scibuntur nomina infantum ${ }^{16}$, sekcja XXXI: pones sal in ore infantis ${ }^{17}$, sekcja XXXV: accipiens acolytus unum ex ipsis infantibus masculum, tenens eum In sinistro brachio; tenens manum super caput infantis ${ }^{18}$, sekcja XLII: mane reddunt infantes symbolum $^{19}$ i wiele innych.

${ }^{11}$ Liber sacramentorum Romanae Aeclesiae ordinis anni circuli. Sacramentarium Gelasianum, red. L. C. Mohlberg, Roma 1960, 193-328, s. $42-43$ (dalej: Ge).

12 Tamże 419-452, s. 67-74

${ }_{13}$ Tamże, 592-617, s. 91-97.

${ }^{14}$ Por. A. Nocent, I tre sacramenti dell'iniziazione cristiana, w: La liturgia, I sacramenti: teologia e storia della celebrazione, red. A. J. Chupungco, Anamnesis 3/1, Casa Editrice Marietti 1992, s. 46-47.

\footnotetext{
${ }^{15}$ Ge 195, s. 33.

16 Tamże 284, s. 42.

17 Tamże 289, s. 43.

18 Tamże 311, s. 48.

19 Tamże 419, s. 67.
} 
Patrząc na Sakramentarz gelazjański w sposób syntetyczny, należy podkreślić, że szafarzami chrześcijańskiej inicjacji byli biskupi i prezbiterzy. Sobie właściwe funkcje wykonywali także diakoni i akolici. Ci ostatni pełnili funkcje związane z egzorcyzmami. Rubryki i teksty dość jasno pokazują, że rytuał inicjacji chrześcijańskiej był przeznaczony dla dzieci.

Teksty i rubryki liturgiczne znajdujące się w Ordo Romanus XI są nieco późniejsze i pochodzą z IX wieku. W księdze tej mamy opis nowej organizacji katechumenatu, uwzględniającej dyscyplinę siedmiu skrutyniów ${ }^{20}$. W Sakramentarzu gelazjańskim były tylko trzy, które tutaj pozostały jako pierwsze, drugie i trzecie. Ta nowość była owocem przystosowań, które uznano wtedy za konieczne. Także tutaj wyraźnie widać, że obrzędy odnoszą się do małych dzieci. Niestety, ich treść i forma zdaje się zupełnie nie uwzględniać rzeczywistej sytuacji dzieci. Można to zobaczyć choćby w skrutyniach, które raczej powinny być praktykowane w przypadkach udzielania sakramentów inicjacji osobom dorosłym. Ordo przewiduje w kościele specjalne miejsce, do którego wynoszono dzieci w sytuacjach, gdy ich obecność nie była konieczna. Można też zaobserwować w obrzędowości inicjacyjnej mnożenie gestów, znaków, modlitw, egzorcyzmów i skrutyniów. Według Adriena Nocenta to wszystko stanowiło formę liturgicznej katechezy dla rodziców dziecka i chrzestnych ${ }^{21}$.

Po krótkim wprowadzeniu do obu starożytnych ksiąg liturgicznych zobaczmy, jak wyglądały obrzędy inicjacji chrześcijańskiej dla dzieci w okresie od VI do VII wieku.

\section{LITURGIA INICJACJI CHRZEŚCIJAŃSKIEJ W SAKRAMENTARZU GELAZJAŃSKIM I W ORDO ROMANUS XI}

Wraz z zanikiem katechezy przygotowującej do chrztu w praktyce przestała istnieć instytucja katechumenatu. Początkowo próbowano zachować obrzędy katechumenalne, ale w odniesieniu do małych dzieci nie miały one żadnego sensu. Według starożytnego Sakramentarza gelazjańskiego i Ordo Romanus XI obrzędy przygotowania do chrztu rozpoczynały się w środę po III niedzieli Wielkiego Postu. Były one zapowiadane już w poniedziałek po III niedzieli Wielkiego Postu. W zapowiedzi tej podkreślano ważność

${ }^{20}$ Zob. Ordo Romanus XI, w: Les Ordines Romani du haut moyen age, red. M. Andrieu, t. 2, Louvain 1971, nr 1-105, s. 417-447 (dalej: OR XI).

${ }^{21}$ Por. A. Nocent, I tre sacramenti dell'iniziazione cristiana, s. 57-58. 
pierwszego spotkania, stanowiącego początek drogi, która doprowadzi do pokonania szatana i otworzy bramy Królestwa Niebieskiego ${ }^{22}$.

W środę, około godziny 9 rano, przy bramie kościoła gromadzili się rodzice i chrzestni ze swymi dziećmi. Po ustawieniu dzieci w dwóch grupach - oddzielnie umieszczano chłopców i dziewczynki (chłopcy po prawej, a dziewczynki po lewej stronie) - kapłan czynił na każdym dziecku znak krzyża, wypowiadając formułę: $W$ imię Ojca i Syna, i Ducha Świętego, następnie nakładał na nie ręce i wypowiadał formułę egzorcyzmu. W modlitwie Omnipotens sempiterne Deus prosił Boga za wezwanych do zaczątków wiary, aby zostali uwolnieni z więzów szatana i krainy ciemności oraz aby wprowadził ich do Kościoła przez przyjęcie sakramentu chrztu ${ }^{23}$.

W tym dniu odbywał się także obrzęd poświęcenia soli. Najpierw, w modlitwie egzorcyzmu soli, przywoływano imię Trójcy Świętej jako źródło istnienia Kościoła i jego fundament. Proszono również, aby sól stała się sakramentem dającym zbawienie i doskonałym lekarstwem oraz by chroniła przed zgubnymi zasadzkami nieprzyjaciela. Po egzorcyzmie sól podawano dzieciom do spożycia, wypowiadając formułę: „Przyjmij sól mądrości przybliżającą ku życiu wiecznemu"24.

$\mathrm{Na}$ zakończenie kapłan odmawiał jeszcze jedną modlitwę, która wiązała się z poprzednim obrzędem poświęcenia i spożycia soli. Modlitwa ta stanowiła formę błogosławieństwa dzieci. W modlitwie zatytułowanej Benedictio post datam sale znajduje się prośba, aby Bóg dopuścił osoby wcześniej spożywające sól do nasycenia niebieskim pokarmem, czyli dał im możliwość uczestnictwa w Eucharystii. Będzie to możliwe po przyjęciu sakramentu chrztu, który jest nazwany „kąpielą nowego narodzenia". Ta kąpiel otwiera drogę do wieczystej nagrody ${ }^{25}$. Następnie wynoszono na chwilę dzieci z kościoła, aby z powrotem je przynieść na początku mszalnej liturgii słowa Bożego.

Po kolekcie zawierającej prośbę za wybranych diakon wzywał: Niech wejda katechumeni. Następnie akolita wywoływał kandydatów do chrztu według kolejności na liście zapisu. Po wejściu kandydatów do kościoła diakon wzywał do cichej modlitwy na klęczkach, którą kończyła aklamacja Amen. Po wezwaniu diakona skierowanego do rodziców

22 OR XI nr 1, s. 417.

${ }^{23}$ Ge $285-287$, s. $42-43$.

${ }^{24}$ Tamże 288-289, s. 43-44.

${ }^{25}$ Tamże 290, s. 44. 
i chrzestnych: „Naznaczcie ich, podejdźcie do błogosławieństwa”, naznaczali oni swoje dzieci. Znak krzyża czyniono na czołach wielkim palcem, wypowiadając formułę: $W$ imię Ojca $i$ Syna, i Ducha Świętego ${ }^{26}$.

Następnie znak krzyża wraz z towarzyszącą mu modlitwą egzorcyzmu wykonywali posługujący w liturgii trzej akolici. Obrzęd, który zastąpił dotychczasowe skrutynia, był powtarzany trzy razy. Wykonywano te same czynności, zmieniając jednak treść modlitwy ${ }^{27}$. Na zakończenie każdego egzorcyzmu również rodzice i chrzestni czynili znak krzyża na swoim dziecku. Po egzorcyzmach dokonanych przez akolitów do każdego dziecka podchodził kapłan i znaczył je znakiem krzyża. Po tym nakładał na dzieci ręce i odmawiał modlitwę Aeternam ac iustissimam pietatem tuam. Po modlitwie w ciszy, do której wzywał diakon, rodzice i chrzestni kolejny raz znaczyli dzieci znakiem krzyża ${ }^{28}$.

Po egzorcyzmach odbywała się liturgia słowa, w której do odczytania Ewangelii uczestniczyły również dzieci. Pierwszym czytaniem była perykopa z Księgi Ezechiela (36,25-29), mówiąca o pokropieniu czystą wodą i oczyszczeniu od wszelkiej zmazy. W proroctwie jest też mowa o nowym sercu i duchu, którego Bóg chce tchnąć w serca ludzi, aby żyli według Bożych przykazań. Po odśpiewaniu graduału dzieci wynoszono z kościoła do specjalnego pomieszczenia na czas trwania liturgii eucharystycznej. Po wyprowadzeniu dzieci odczytywano fragment Ewangelii według św. Mateusza, w którym Jezus wychwala Ojca za objawienie tajemnic Królestwa Niebieskiego prostaczkom (11,25-30) ${ }^{29}$.

Okres chrzcielnego przygotowania obejmował także obrzęd "otwarcia uszu na słowo Boże i na prawdę Bożą". Odbywał się on w czasie liturgii słowa i polegał na przekazaniu Ewangelii. Najpierw odczytywano perykopę z Księgi Izajasza $(55,2-7)$ i z Listu św. Pawła Apostoła do Kolosan (3,9-10) z odpowiednimi responsoriami: Venite filii i Beata gens. Obrzęd zawierał również przyniesienie Ewangelii do ołtarza oraz katechezę o jej ważności, zawartości i znaczeniu. Do ołtarza diakoni przynosili cztery księgi Ewangelii jako symbol czterech ewangelistów. Księgi składano na czterech rogach ołtarza. W procesji uczestniczyli także akolici z dwoma świecami i osoba niosąca kadzielnicę. Kapłan wprowadzał wszystkich w znaczenie obrzędu i na podstawie Księgi Ezechiela

\footnotetext{
${ }^{26}$ OR XI, 12, s. 420.

27 Zob. Ge 291-297, s. 44-45.

${ }^{28}$ OR XI, 13-27, s. 420-424.

${ }^{29}$ Tamże 28-32, s. 424-425.
} 
(1,5-12) wyjaśniał symboliczne wyobrażenie wszystkich ewangelistów. Księgi Ewangelii są tutaj nazywane „czynami Boga” i Dobrą Nowiną, która zwiastuje Jezusa Chrystusa. Katecheza wygłaszana przez kapłana prowadziła do symbolicznego otwarcia uszu kandydatów do chrztu. Po katechezie diakon wzywał wszystkich do milczenia i do uważnego słuchania. Następnie diakoni podchodzili do ołtarza, brali księgę Ewangelii i odczytywali wybraną perykopę. Po odczytaniu Ewangelii subdiakon odbierał księgę i niosąc ją na płótnie, zanosił do zakrystii. Następnie kapłan wyjaśniał jej treść. Czynność czytania i wyjaśniania Ewangelii była wykonywana cztery razy. Odczytywano następujące perykopy ewangeliczne: Mt 1,1-22, Mk 1,1-8, Łk 1,1-17 i J 1,1-14².

W tym dniu odbywało się także "przekazanie Symbolu wiary”. Ten obrzęd miał miejsce bezpośrednio po odczytaniu czterech Ewangelii. Przypominano wszystkim zgromadzonym podstawowe prawdy chrześcijańskiej wiary zawarte w Składzie Apostolskim. Kapłan we wprowadzeniu zachęcał do przyjęcia wiary sercem, bo dzięki temu dzieci otrzymają łaskę usprawiedliwienia w sakramencie chrztu. Skład Apostolski jest nazwany "sakramentem ewangelicznego Symbolu", który kryje w sobie wielkie misteria. Jego autorem jest Duch Święty, który dyktował nauczycielom Kościoła ten pożyteczny i łatwy skrót prawd chrześcijańskiej wiary ${ }^{31}$. Po katechezie wyjaśniającej znaczenie Symbolu wiary akolita brał chłopca na lewe ramię i kładł prawą rękę na jego głowie. Następnie w jego imieniu wyznawał wiarę, śpiewając Symbol. Czynność tę powtarzano z dziewczynkami. Najpierw wyznawano wiarę w języku greckim, a potem w języku łacińskim. Obrzęd kończył się jeszcze jedną katechezą celebransa o znaczeniu Symbolu wiary ${ }^{32}$.

Kolejnym elementem trzeciego skrutynium było przekazanie Modlitwy Pańskiej. Diakon wzywał wszystkich do zachowania milczenia, a kapłan wygłaszał katechezę na temat poszczególnych wezwań tejże modlitwy. Podkreślał, że jest to modlitwa pochodząca od samego Jezusa, który zachęcał swoich uczniów do modlitwy i jej uczył. Zachęcał także, aby przyjąć do serca misteria, które są obecne w modlitwie Ojcze nasz. Ta modlitwa przybliża do Boga i do Królestwa Niebieskiego. Po tych obrzędach celebrowano Eucharystię, w której nie mogły uczestniczyć nieochrzczone dzieci ${ }^{33}$.

30 Tamże 39-60, s. 426-433; Ge 329-309, s. 46-48.

31 Ge 310, s. 48; OR XI 61, s. 433.

32 Tamże 311-318, s. 4851; OR XI 61-67, s. 433-437.

33 Tamże 319-328, s. 51-53: OR XI 68-72, s. 437-441. 
Ostatnie spotkanie przedchrzcielne odbywało się w Wielką Sobotę rano. Po przyjściu do kościoła ustawiano oddzielnie chłopców i dziewczynki. To ostatnie skrutynium przed udzieleniem chrztu jest nazwane katechizacją i zwrotem Symbolu. Obrzęd składał się ze znaku krzyża, którym kapłan znaczył wszystkie dzieci, nałożenia rąk i egzorcyzmu, dotknięcia śliną nozdrzy i uszu poszczególnych dzieci, wypowiedzenia słów Effeta, to znaczy "otwórz się, na wdzięczną woń”, zwrotu Symbolu Wiary i Modlitwy Pańskiej. Ostatnią część wykonywał sam kapłan i dlatego miała znaczenie tylko symboliczne ${ }^{34}$.

Sakramentu chrztu udzielano podczas celebracji Wigilii Paschalnej, która rozpoczynała się w sobotę wieczorem. Liturgia rozpoczynała się od procesji do źródła chrzcielnego. W czasie procesji rozbrzmiewał śpiew litanijny. Przy źródle chrzcielnym odbywały się następujące obrzędy: poświęcenie świec, czytania biblijne, litania i poświęcenie wody. Po odmówieniu modlitwy poświęcenia wodys biskup wylewał olej krzyżma do wody, czyniąc znak krzyża i mieszając wodę z olejem. Następnie kropił poświęconą wodą wszystkich zebranych. Wierni mogli wziąć poświęconą wodę, aby pokropić nią własne domy i pola ${ }^{35}$.

Chrztu osobiście udzielał biskup wraz z towarzyszącymi mu diakonami. Biskup osobiście chrzcił zwykle jedno lub kilkoro dzieci. Pozostałe dzieci były chrzczone przez diakonów na polecenie biskupa. Chrzest odbywał się przez potrójne zanurzenie, któremu towarzyszyła formuła trynitarna: Ja ciebie chrzczę w imię Ojca i Syna, i Ducha Świętego. Dziecko zaraz po chrzcie odbierali chrzestni i przynosili je kapłanowi, aby namaścił je na szczycie głowy świętym olejem. Następnie dzieci zanoszono do biskupa, który wręczał im szatę chrzcielną i dziesięć sykli36.

Po chrzcie dzieci przyjmowały sakrament bierzmowania i uczestniczyły w Eucharystii. Bierzmowania udzielał biskup. Najpierw odmawiał modlitwę, w której prosił o siedem darów Ducha Świętego, następnie namaszczał czoła dzieci olejem krzyżma, wypowiadając formułę: $W$ imię ojca $i$ Syn, i Ducha Świętego ${ }^{37}$ lub: Znak Chrystusa na życie wieczne ${ }^{38}$. Po namaszczeniu biskup przekazywał znak pokoju ${ }^{39}$.

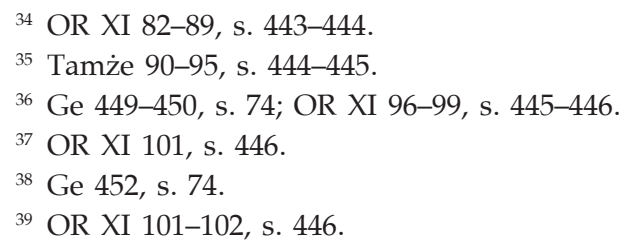


Eucharystię rozpoczynano od hymnu Chwata na wysokości Bogu. W czasie Mszy św. wszystkie ochrzczone dzieci przyjmowały komunię św. Modlitwy liturgiczne sprawowanej Eucharystii zawierają motywy chrzcielne: światło, przełom, zwycięstwo, nowe życie, nowe narodziny ${ }^{40}$.

Po przyjęciu wszystkich trzech sakramentów inicjacji chrześcijanskiej dzieci wraz z rodzicami przez cały tydzień miały przychodzić do kościoła, aby przyjmować komunię św. Rodzice w imieniu swoich dzieci składali dary przy ołtarzu ${ }^{41}$.

\section{ZAKOŃCZENIE}

Podsumowując, należy zwrócić uwagę, że rozbudowane obrzędy przygotowujące do chrztu były zupełnie nieadekwatne do rzeczywistej sytuacji małych dzieci. Szczególnie skrutynia, będące pozostałością dawnego katechumenatu, były sztuczne $\mathrm{w}$ odniesieniu do dzieci. W tym przypadku nie było mowy o realnym uczestnictwie dzieci $\mathrm{w}$ procesie przygotowania do chrztu. Trudno też było za każdym razem gromadzić rodziców z dziećmi na dość długim przygotowaniu do przyjęcia sakramentów inicjacji chrześcijańskiej.

Następne okresy nie przyniosły większych zmian $w$ tej kwestii. Nadal chrzczono dzieci, posługując się rytuałem dla dorosłych, dokonując jedynie niewielkich adaptacji. Dopiero po reformie Soboru Watykańskiego II powstała księga zawierająca obrzędy chrztu dostosowane do rzeczywistości małych dzieci. Jest to księga Ordo baptismi paroulorum.

Streszczenie. Artykuł przedstawia obrzędy chrzcielne umieszczone w dwóch starożytnych księgach, zawierających opis liturgii chrzcielnej dzieci z okresu między VI a IX wiekiem. Są to: Sakramentarz gelazjański i Ordo Romanus XI. Od VI wieku zmieniła się praktyka chrzcielna Kościoła. Ponieważ zaczęto masowo chrzcić małe dzieci, straciła rację bytu instytucja katechumenatu, która wcześniej przygotowywała kandydatów do przyjęcia sakramentów inicjacji chrześcijańskiej. W księgach liturgicznych, które zachowały ogólny schemat dawnego katechumenatu, pojawiły się wyraźne wskazania, modlitwy i obrzędy odnoszące się bezpośrednio do małych dzieci. Trzeba jednak podkreślić, że mimo prób pewnych adaptacji, nie udało się w tamtym okresie stworzyć obrzędów, które byłyby adekwatne do rzeczywistej

${ }^{40}$ Ge $453-462$, s. $75-76$.

${ }^{41}$ OR XI 104-105, s. 447. 
sytuacji chrzczonego dziecka. Artykuł omawia także w skrócie nauczanie Kościoła starożytnego dotyczącego chrztu dzieci.

Słowa kluczowe: Chrzest; chrzest dzieci; obrzędy chrzcielne; formuła chrzcielna; katechumenat; inicjacja chrześcijańska; skrutynia; Sakramentarz gelazjański; Ordo Romanus XI.

Summary: The article presents the Baptismal rites which are included in two ancient ritual books with instructions for the liturgy of infants' Baptism between the VI and IX centuries. These liturgical books are the Gelasian sacramentary and the Ordo Romanus XI. From the VI century there had been a change in the baptismal practice of the Church. Due to a vast increase in the number of infants' Baptisms, the catechumenate institution was no longer needed, since it had served the purpose of instructing candidates for the reception of the Sacraments of Christian initiation. The liturgical books which preserved the overall structure of the former catechumenate now included clear instructions, prayers and rites which referred directly to small children. It has to be emphasized, though, that in spite of many suggested adaptations, the attempt to create rites which would adequately address the actual situation of a baptized child were unsuccessful. The article also includes a short presentation of the ancient Church's teaching on the Baptism of infants.

Keywords: Baptism; Baptism of infants; baptismal rites; baptismal formula; catechumenate; Christian initiation; scrutinies; Gelasian sacramentary; Ordo Romanus XI. 